\title{
OBITELJSKA MEDIJACIJA I MOGUĆNOSTI PRIMJENE U SLUČAJEVIMA MEĐUNARODNE OTMICE DJECE
}

Izv. prof. dr. sc. Vanja Branica*

Prof. dr. sc. Irena Majstorović**

Doc. dr. sc. Ivan Šimović***
UDK: 347.627 .028

347.9:347.61/.64-053.2

DOI: $10.3935 /$ zpfz.71.2.03

Izvorni znanstveni rad

Primljeno: svibanj 2021.

Međunarodna otmica djece fenomen je koji dugo zaokuplja pozornost stručnjaka. Ipak, pozornosti unatoč, čini se da su načini prevladavanja ovih teških situacija nerijetko predmetom spoticanja različitih struka. Svrha je ovoga rada stoga višsstruka. Prvo, iz zajedničke perspektive prava i socijalnog rada dodatno rasvijetliti mogućnosti koje obiteljska medijacija općenito nudi kao instrument rješavanja složenih sukoba i obiteljskih sporova. Drugo, analizirati prednosti koje korištenje obiteljske medijacije donosi u predmetima međunarodne otmice djece. I konačno, nastojati interdisciplinarno ujediniti uvid u ključne pravne izvore sa spoznajama o praktičnim izazovima provedbe medijacijskih postupaka kako bi vrijednost medijacije u predmetima međunarodne otmice djece postala što prepoznatija.

Ključne riječi: obiteljska medijacija, međunarodna otmica djece, Haška konvencija o gradanskopravnim vidovima otmice djece, obiteljsko pravo

* Dr. sc. Vanja Branica, izvanredna profesorica Pravnog fakulteta Sveučilišta u Zagrebu, Trg Republike Hrvatske 14, 10000 Zagreb; vanja.branica@pravo.hr;

ORCID ID: orcid.org/0000-0001-5184-6645

** Dr. sc. Irena Majstorović, profesorica Pravnog fakulteta Sveučilišta u Zagrebu, Trg Republike Hrvatske 14, 10000 Zagreb; irena.majstorovic@pravo.hr; ORCID ID: orcid.org/0000-0002-4937-5968

**** Dr. sc. Ivan Šimović, docent Pravnog fakulteta Sveučilišta u Zagrebu, Trg Republike Hrvatske 14, 10000 Zagreb; isimovic@pravo.hr;

ORCID ID: orcid.org/0000-0002-0222-5073 


\section{UVODNE NAPOMENE}

Tema ovoga rada mogućnosti su primjene obiteljske medijacije u slučajevima međunarodne otmice djece. ${ }^{1}$ Obiteljska medijacija općenito se određuje kao postupak alternativnog rješavanja sukoba i sporova u kojem članovi obitelji nastoje doći do zajednički prihvatljivog rješenja spornih pitanja uz pomoć treće nepristrane i neutralne osobe. Međunarodnom otmicom djece smatra se svako nezakonito odvođenje ili zadržavanje djeteta preko granice države u kojoj je imalo uobičajeno boravište bez pristanka ili znanja drugog roditelja, koje rezultira povredom "prava na skrb" - svih prava koja se odnose na skrb o osobi djeteta. ${ }^{2}$

Otmica djeteta uvijek je iznimno stresan događaj za djecu i roditelje te ima brojne pravne i psihološke te socijalne posljedice. Svakako, brojne poteškoće nastupaju i ako dođe do "mijenjanja djetetovih životnih i razvojnih uvjeta unutar granica jednog pravnog sustava" ${ }^{3}$ no mogućnost pravne intervencije u nacionalnim je okvirima bitno veća. Kada se otmica dogodi u međunarodnom

1 U radu će se koristiti pojam "međunarodna otmica djece”, koji obuhvaća ne samo međunarodne otmice djece koje su počinili roditelji, već i one međunarodne otmice koje su počinili ostali članovi djetetove obitelji, dakle riječ je o obiteljskopravnom, a ne kaznenopravnom pojmu.

2 O sadržaju, smislu i dosegu definicije međunarodne otmice djece podrobnije u: Pérez-Vera, E., Explanatory Report on the 1980 Hague Child Abduction Convention, dostupno na: http://hcch.e-vision.nl/upload/expl28.pdf (15. travnja 2021.), par. 64-74; European Union Agency for Fundamental Rights and Council of Europe, Handbook on European law relating to the rights of the child, Luxembourg, 2015., str. 86, dostupno na: https://fra.europa.eu/sites/default/files/fra_uploads/fra-ecthr-2015-handbook-european-law-rights-of-the-child_en.pdf (15. travnja 2021.); Župan, M.; Drventić, M.; Kruger, T., Cross-border removal and retention of a child-Croatian Practice and European Expectation, International Journal of Law, Police and The Family, vol. 34, br. 1, 2020., str. 60; Medić Musa, I.; Božić, T., Haška konvencija o građanskopravnim aspektima međunarodne otmice djeteta (1980) - casus belli, u: Rešetar, B. (ur.), Pravna zaštita prava na (zajedničku) roditeljsku skrb, Pravni fakultet Osijek, Osijek, 2012. str. 165 - 166; Šimović, I.; Majstorović, I., Povreda prava na obiteljski život u postupcima međunarodne otmice djece: o značenju načela žurnog postupanja, Hrvatska pravna revija, vol. 17, br. 11, 2017., str. 2. O tome što se ima smatrati međunarodnom otmicom djeteta te kako pravilno primijeniti odredbu čl. 3. Konvencije o građanskopravnim vidovima međunarodne otmice djece, stajalište je zauzeo i Europski sud za ljudska prava (dalje u tekstu: ESLJP). Vidi presude ESLJP-a u predmetima R. S. protiv Poljske, br. 63777/09, 21. srpnja 2015., par. 66. i Andersena protiv Latvije, br. 79441/17, 19. rujna 2019., par. 114. - 115 .

3 Tako: Hrabar, D., Porodičnopravna zaštita djece državljana SFRJ odvedene u inozemstvo protivno odluci suda o njihovu čuvanju i odgoju, Zbornik Pravnog fakulteta u Zagrebu, vol. 39, 1989., br. 1, str. 46. 
okružju, tada su pravne posljedice dodatno komplicirane jer uključuju primjenu više različitih nacionalnih zakonodavstava i primjenu međunarodnih globalnih i regionalnih dokumenata. ${ }^{4} \mathrm{O}$ psihološkim i socijalnim posljedicama bit će kasnije riječi, ali važno je razumjeti da su komplicirani i odnosi među roditeljima, često vrlo narušeni s prisutnom visokom razinom sukoba, nepovjerenja i neslaganja. $S$ obzirom na to da se postupanje tada odvija u vrlo zahtjevnom okružju pravnih, psiholoških i socijalnih aspekata međunarodne otmice djece, važna je suradnja $\mathrm{i}$ interdisciplinarno djelovanje u cilju zaštite prava djece.

Najvažniji međunarodni globalni dokument koji regulira pitanje međunarodne otmice djeteta je Konvencija o građanskopravnim vidovima međunarodne otmice djece iz 1980. godine, usvojena u okviru Haške konferencije za međunarodno privatno pravo (dalje u tekstu: Haška konvencija). ${ }^{5}$ Haška konvencija predviđa sporazumno rješavanje pitanja povratka djeteta i drugih pitanja vezanih uz dijete, a jedan od mogućih postupaka je obiteljska medijacija (čl. 10. u vezi s čl. 7. st. 2. t. c) Haške konvencije). ${ }^{6}$ Ideju obiteljske medijacije kao korisne mogućnosti mirnog rješavanja obiteljskopravnog spora slijedi čitav niz dokumenata, donesenih na razini Vijeća Europe i Europske unije te na razini nacionalnoga hrvatskog prava, o čemu više infra.

Svrha je ovoga rada stoga prikazati relevantne pravne dokumente, od globalne, preko regionalne do nacionalne razine, čemu se pridodaju razmatranja provedbe obiteljske medijacije u slučajevima međunarodne otmice djece te se predlažu načini dodatnog usavršavanja sustava, koji bi trebao postići dva cilja: spriječiti međunarodnu otmicu djece te, podredno, ako je otmica već počinjena, osigurati brz povratak djeteta iz države u koju je protupravno odvedeno, odnosno u kojoj je protupravno zadržano. ${ }^{7} \mathrm{Na}$ taj bi se način dodatno oživotvorilo

4 Na problem kompleksne primjene nacionalnih i međunarodnih pravnih izvora $\mathrm{u}$ slučajevima međunarodne otmice djece upućuju i službeni dokumenti Haške konferencije za međunarodno privatno pravo - Guide to Good Practice under the Hague Convention of 25 October 1980 on the Civil Aspects of International Child Abduction Mediation, par. 42., dostupno na: https://assets.hcch.net/docs/d09b5e94-64b4-4afe8eel-ab97c98daa33.pdf (15. travnja 2021.).

5 Narodne novine, Međunarodni ugovori, br. 8/2018.

6 O tome podrobnije u: Pérez-Vera, op. cit. u bilj. 2, par. 92. i 103. Vidi i: Župan, M.; Šego, M., Medijacija u prekograničnim obiteljskim postupcima, u: Župan, M. (ur.), Prekogranično kretanje djece u Europskoj uniji, Pravni fakultet Sveučilišta Josipa Jurja Strossmayera u Osijeku, Osijek, 2019., str. 403.

7 Da su upravo to osnovni ciljevi koji se nastoje postići sustavom koji se temelji na Haškoj konvenciji i ostalim međunarodnim, ali i nacionalnim pravnim dokumentima, potvrđuju pravna teorija i sudska praksa. Vidi: Vajić, N., The Interaction between the European Court of Human Rights and the Hague Child Abduction Convention, 
zalaganje hrvatskoga sustava za ostvarenje načela najboljeg interesa djeteta kao primarnog cilja suvremenih pravnih sustava i društava u cjelini.

\section{PRAVNI OKVIR UREĐENJA MEĐUNARODNE OTMICE DJECE: OD GLOBALNE DO NACIONALNE RAZINE}

Međunarodne otmice djece dugo zaokupljaju pozornost svjetske stručne i šire javnosti. Naime, premda je sada možda aktualnije nego ikada, pitanje međunarodne otmice djece nije novo. Na globalnoj su se razini prve naznake pravnoga uređenja ocrtale sedamdesetih godina prošloga stoljeća. U okviru Haške konferencije za međunarodno privatno pravo počeli su pregovori o usvajanju novog instrumenta koji je trebao biti, a bez sumnje je to i postao, "kamenom temeljcem međunarodnog obiteljskog prava", čija je svrha bila zaustaviti sve više prevladavajuće zlo oduzimanja djece. ${ }^{8}$ Vrlo je brzo postalo jasno da usvajanje takvoga dokumenta nije dostatno, tim više što je razvidno da posebni izazovi nastaju ako je dijete protupravno odvedeno ili zadržano u državi koja nije dio sustava Haške konferencije ${ }^{9}$, stoga su i na regionalnoj i na nacionalnoj razini uvedena posebna pravila, o kojima više infra.

u: Župan, M., (ur.), Private International Law in the Jurisprudence of European Courts - Family at Focus, Faculty of Law Osijek, Josip Juraj Strossmayer University of Osijek, Osijek, 2015.; Šeparović, M., Dobrobit djeteta i najbolji interes djeteta u sudskoj praksi, Novi informator, Zagreb, 2014., str. 138 - 139; Mandija, L., Cross-border Disputes over Child Custody and Access Rights and the ECtHR Jurisprudence in the Case of Albania, u: Brinig, M. (ur.), International Survey of Family Law 2018, Intersentia, Cambridge - Antwerp - Chicago, 2018., str. 58; Khazova, O. A.; Mezmur, B. D., UN Committee on the Rights of the Child - Continued Reflections on Family Law Issues in the Jurisprudence of the CRC Committee: The Convention on the Rights of the Child@30, u: Brinig, M. (ur.), International Survey of Family Law 2020, Intersentia, Cambridge - Antwerp - Chicago, 2020., str. 340 - 342; Medić Musa; Božić, op. cit. u bilj. 2, str. 164; str. 285; Šimović; Majstorović, op. cit. u bilj. 2, str. 3.

U tom smislu vidi presudu Velikog vijeća ESLJP-a u predmetu X protiv Latvije, br. 27853/09, 26. studenoga 2013., par. 35. te presudu Suda Europske unije u predmetu Doris Povse protiv Mauro Alpago (C-211/10 PPU, ECLI:EU:C:2010:400, par. 43.).

8 Thorpe, M., Mediation to resolve child abduction issues for Hague and Non-Hague convention countries, Singapore Academy of Law Journal, vol. 30, Special issue, 2018., str. 576; Jakovac-Lozić, D.; Klarin, A., Međunarodne otmice djece od strane roditelja, Zbornik radova Pravnog fakulteta u Splitu, vol. 34, br. 45-46, 1997., str. 75 i 80 - 84.

9 M. Thorpe granicu preko koje je dijete odvedeno naziva "zatvorskim zidom" koji ne samo da priječi povratak djeteta, nego često predstavlja i prepreku održavanja kontakata. Thorpe, op. cit. u bilj. 8, str. 580. Navedenu tezu o postojanju posebnih izazova i problema u prevenciji, odnosno uspješnom rješavanju slučajeva međunarodne 


\subsection{Haška konferencija za međunarodno privatno pravo}

Najvažniji globalni dokument koji uređuje pitanja građanskopravne otmice djece usvojen je u okviru Haške konferencije za međunarodno privatno pravo. Riječ je dakako o Haškoj konvenciji, odnosno Konvenciji o građanskopravnim vidovima međunarodne otmice djece od 25. listopada 1980. godine, koja danas okuplja 101 državu ugovornicu. ${ }^{10}$ Republika Hrvatska postala je ugovornicom na temelju notifikacije o sukcesiji, a vrijedi napomenuti da je interes za taj dokument nastavljen te da je 2018. godine stupio na snagu provedbeni propis, prikazan u ovome radu.

Važna poruka toga dokumenta, koja je na razini Ujedinjenih naroda kasnije potvrđena Konvencijom o pravima djeteta (čl. 11. $)^{11}$, jest da su "interesi djece u pitanjima skrbi o njima od iznimne važnosti” te da djecu treba “zaštititi na međunarodnoj razini od štetnih posljedica protupravnog odvođenja ili zadržavanja i utvrditi postupke koji osiguravaju brzi povratak djece u njihovo uobičajeno boravište, kao i osigurati zaštitu prava na kontakte s djetetom". ${ }^{12}$

Osnovni su ciljevi Haške konvencije osigurati što brži povratak djece protupravno odvedene ili zadržane u nekoj državi ugovornici te osigurati da se pravo na skrb o djetetu i pravo na kontakte prema pravu jedne države ugovornice dosljedno poštuju u ostalim državama ugovornicama. ${ }^{13}$ Drugim riječima, riječ je o kompromisu ponajprije usmjerenom na to da se ponovno uspostavi status $q u o^{14}$, točnije da se uspostavi status quo ante djeteta. ${ }^{15} \mathrm{Na}$ taj način žele se ublažiti

otmice djece za države koje nisu stranke Haške konvencije potvrdio je i ESLJP u predmetu Bajrami protiv Albanije, br. 35853/04, 12. prosinca 2006., par. 65. - 67.

10 Prema: https://www.hcch.net/en/instruments/conventions/status-table/?cid=24 (15. travnja 2021.).

11 Konvencija o pravima djeteta, Službeni list SFRJ, Međunarodni ugovori, br. 15/1990. Preuzeta u pravni poredak Republike Hrvatske na temelju notifikacije o sukcesiji, Narodne novine, Međunarodni ugovori, br. 12/1993. i 20/1997.

12 Preambula Haške konvencije. Zanimljivo je i ohrabrujuće vidjeti potvrdu citiranih pravnih polazišta u sudskoj praksi najvažnijih europskih sudova - ESLJP-a i Suda Europske unije. Vidi presudu ESLJP-a u predmetu Maumousseau i Washington protiv Francuske, br. 39388/05, 6. prosinca 2007., par. 71. i presudu Suda Europske unije u predmetu OL v PQ (C-111/17 PPU, ECLI:EU:C:2017:436), par. 3. - 4. i 57.

13 Čl. 1. Haške konvencije.

14 Pérez-Vera, op. cit. u bilj. 2, par. 16.; Vajić, op. cit. u bilj. 7, str. 285; Medić Musa; Božić, op. cit. u bilj. 2, str. 164; Šeparović, op. cit. u bilj. 7, str. 138 - 139; Šimović; Majstorović, op. cit. u bilj. 2, str. 3.

15 Tako i Hrabar, op. cit. u bilj. 3, str. 49. 
posljedice izazvane međunarodnom otmicom kod djeteta te se povratkom djeteta pokušava vratiti i osjećaj sigurnosti, ali i osigurati da se o svim relevantnim pitanjima vezanim uz dijete odlučuje u postupcima pred sudom one države u kojoj je dijete živjelo neposredno prije nezakonitog odvođenja ili zadržavanja, u kojoj se raspolaže s najvećim brojem informacija o djetetu.

Države potpisnice koje primjenjuju Hašku konvenciju dužne su odrediti središnje tijelo postupanja u slučajevima otmice djece koje će poduzimati potrebne mjere, samostalno ili preko posrednika. ${ }^{16} \mathrm{U}$ Republici Hrvatskoj kao središnje tijelo određeno je ministarstvo nadležno za poslove socijalne skrbi, službe koje se bave podrškom obitelji. Analiza dostupnih podataka za posljednjih petnaest godina upućuje na to da je godišnje prosječno postupano u 20 slučajeva, a od toga u odnosu na djecu koja su odvedena iz Republike Hrvatske u 12 slučajeva. ${ }^{17}$

U pravnoj se teoriji smatra da je Haška konvencija ostvarila svoj cilj i izdržala test vremena. ${ }^{18}$ Međutim, činjenica jest da je najveći nedostatak to što ne određuje ni mehanizam provedbe odluke ni nadzorno tijelo koje bi osiguravalo da države ugovornice pravilno primjenjuju njezine odredbe. ${ }^{19}$ Stoga se na europskoj regionalnoj, kao i na nacionalnim razinama odavno razvijaju pravni

16 Mjere koje Središnje tijelo, sukladno članku 7. Haške konvencije, treba provoditi jesu, posebice, poduzimanje svih odgovarajućih mjera za otkrivanje mjesta gdje se nalazi dijete koje je protupravno odvedeno ili zadržano; sprječavanje daljnjih opasnosti za dijete ili predrasuda u odnosu na jednu od zainteresiranih strana, poduzimanjem ili predlaganjem poduzimanja privremenih mjera; osiguranje dobrovoljnog vraćanja djeteta ili lakše postizanje sporazumnog rješenja; razmjena, prema potrebi, informacija u vezi sa socijalnim okruženjem djeteta; pružanje općih informacija o važećem pravu u njihovoj državi u vezi s primjenom Konvencije; pokretanje ili olakšavanje pokretanja sudskog ili upravnog postupka radi osiguranja povratka djeteta i, ovisno o slučaju, poduzimanja mjera radi organiziranja ili osiguravanja učinkovitog ostvarivanja prava na kontakte; pružanje ili, ovisno o slučaju, olakšavanje dobivanja pravne pomoći i savjeta, uključujući i sudjelovanje branitelja i pravnih savjetnika; osiguranje onih upravnih mjera koje su potrebne i prikladne za siguran povratak djeteta te osiguravanje uzajamne razmjene informacija o funkcioniranju Konvencije i, koliko je to moguće, otklanjanja svih prepreka do kojih može doći u njezinoj primjeni.

17 Navedeno prema godišnjim statističkim izvješćima o primijenjenim pravima socijalne skrbi, pravnoj zaštiti djece, mladeži, braka, obitelji i osoba lišenih poslovne sposobnosti te zaštiti tjelesno ili mentalno oštećenih osoba u Republici Hrvatskoj od 2003. do 2019. godine, dostupno na stranicama resornog ministarstva: https:// mrosp.gov.hr/strategije-planovi-programi-izvjesca-statistika/4165 (15. travnja 2021.).

18 Thorpe, op. cit. u bilj. 8, str. 576; Medić Musa; Božić, op. cit. u bilj. 2, str. 188.

19 Cunha, E., The potential importance of incorporating online dispute resolution into a universal medation model for international child abduction cases, Connecticut journal of inter- 
instrumenti kojima je cilj dodatno osnažiti primjenu Haške konvencije te time pridonijeti stvaranju sustava brze uspostave prijašnjeg stanja.

\subsection{Vijeće Europe}

Na razini Vijeća Europe pitanje međunarodne otmice djece davno je prepoznato, no unatoč tome nije usvojen jedinstven instrument koji bi predstavljao sedes materiae za ovo područje. Međutim, isticanje vrijednosti pravilne i pravodobne primjene odredaba Haške konvencije iščitava se iz brojnih dokumenata.

Od navedenih ponajprije valja istaknuti Konvenciju o kontaktima s djecom. ${ }^{20}$ Naime, otmicom po prirodi stvari prestaju kontakti djeteta s drugim roditeljem, kao i ostalim bliskim osobama, a osim toga u svakom pojedinom slučaju nakon povratka djeteta u matičnu državu treba osobito pažljivo procijeniti kako pristupiti ponovnoj uspostavi kontakata. Naime, protek vremena dovodi do udaljavanja djeteta od članova obitelji s kojima nije u redovitijem kontaktu te je potrebno uložiti dodatne napore u ponovnu uspostavu odnosno osnaživanje veza koje su postojale prije otmice.

Stoga se, među ostalim, pozivom upravo na Hašku konvenciju (čl. 21.), na čiju primjenu Konvencija o kontaktima ne utječe, određuju tri temeljna cilja ovoga dokumenta. ${ }^{21}$ Prvo, odrediti opća načela koja će se primjenjivati na odluke o kontaktima. Drugo, utvrditi odgovarajuće mjere osiguranja i jamstva kako bi se osiguralo pravilno izvršenje kontakata i trenutačni povratak djece na kraju vremena koje je određeno za kontakte. I treće, uspostaviti suradnju između središnjih tijela, pravosudnih tijela i drugih tijela u cilju promicanja i poboljšanja kontakata između djece i njihovih roditelja te drugih osoba s kojima su djeca u obiteljskoj vezi.

Europska konvencija o ostvarivanju dječih prava ${ }^{22}$ također je važan instrument zaštite prava djece i u slučajevima međunarodne otmice. Predmet je ove Konvencije, sukladno članku l., promicati prava djece u skladu s njihovim najboljim interesima, dodijeliti im postupovna prava i olakšati im ostvarivanje tih prava na način da se osigura da djeca, sama ili posredstvom drugih osoba ili tijela, budu obaviještena i da im bude dopušteno sudjelovati u postupcima pred sudbenim

national law, vol. 24., br. 1, 2008., str. 163; Medić Musa; Božić, op. cit. u bilj. 2, str. 182; Župan; Šego, op. cit. u bilj. 6, str. $397-398$.

20 Narodne novine, Međunarodni ugovori, br. 7/2008.

21 Članak 1. Konvencije o kontaktima s djecom.

22 Narodne novine, Međunarodni ugovori, br. 1/2010. 
tijelima koji ih se tiču, što uključuje i postupke u kojima se odlučuje o zahtjevu za povratkom nezakonito odvedenog ili zadržanog djeteta po Haškoj konvenciji.

Veliku vrijednost ima i odredba Preambule u kojoj se ističe da je u slučaju sukoba između članova obitelji poželjno da obitelji pokušaju postići dogovor prije iznošenja tog pitanja pred sudbeno tijelo. Alternativno rješavanje spora dodatno se potiče člankom 13., u kojem se propisuje: "u cilju sprječavanja ili rješavanja sporova ili izbjegavanja postupka pred sudbenim tijelima koji se tiču djece, stranke će, u odgovarajućim slučajevima koje će same odrediti, poticati posredovanje i druge postupke rješavanja sporova i primjenjivanje tih postupaka u postizanju sporazuma."

U okviru Vijeća Europe usvojene su i Preporuka br. R (98) Odbora ministara državama članicama o obiteljskoj medijaciji iz $1998 .{ }^{23}$ te Smjernice za bolju provedbu postojeće preporuke o obiteljskoj medijaciji i medijaciji u građanskopravnim stvarima. ${ }^{24}$

\subsection{Europska unija}

U dokumentima Europske unije dugo se ističe značenje rješavanja obiteljskih prijepora u situacijama s tzv. međunarodnim elementom. Ključan dokument sada na snazi, relevantan za temu rada, jest Uredba Vijeća (EZ) br. 2001/2003 od 27. studenoga 2003. o nadležnosti, priznavanju i izvršenju sudskih odluka u bračnim sporovima i u stvarima povezanim s roditeljskom odgovornošću, kojom se stavlja izvan snage Uredba (EZ) br. 1347/200025, a uvriježeno se naziva Uredbom Bruxelles II bis ili Bruxelles IIa, koja u dijelu svojeg sadržaja uređuje ista pitanja kao i Haška konvencija.

Važno je stoga naglasiti da je člankom 60. Uredbe propisano da će u odnosima između država članica Uredba, sukladno načelu supremacije europskoga prava, imati prednost u primjeni pred Haškom konvencijom u onoj mjeri u kojoj se ona odnosi na predmete otmice djece između država članica Europske unije

23 Recommendation no. R (98) 1 of the Committee of Ministers to Member states on Family Mediation, dostupno na: https://rm.coe.int/CoERMPublicCommonSearchServices/DisplayDCTMContent?documentId=09000016804ecb6e (15. travnja 2021.). O Preporuci više: Alinčić, M., Europsko viđenje postupka obiteljskog posredovanja, Revija za socijalnu politiku, vol. 6, br. 3-4, 1999., str. 227 - 235.

24 Guidelines for a better implementation of the existing recommendation concerning family mediation and mediation in civil matters, dostupno na: https://rm.coe.int/16807475b6 (15. travnja 2021.).

25 Službeni list Europske unije, L 338, 23. prosinca 2003., L 46, 18. veljače 2014. 
("intra-EU child abduction cases"). U skladu s člankom 60. Uredbe Haška konvencija i dalje proizvodi pravne učinke između država članica koje su njezine potpisnice te uređuje sve situacije koje nisu izrijekom uređene Uredbom. ${ }^{26}$

Ipak, sustavnosti radi, ističemo otklon koji Uredba čini vezano uz uređenje predaje djeteta u članku 11., od čega izdvajamo dva važna elementa. Prvo, sud ne može odbiti predaju djeteta na temelju članka 13. stavka (b) Haške konvencije ako je utvrđeno da su poduzete sve potrebne mjere za zaštitu djeteta nakon njegova povratka. I drugo, sud ne može odbiti predaju djeteta, a da prije toga ne pruži mogućnost saslušanja osobe koja zahtijeva predaju djeteta. Konačno, treba istaknuti još jedan otklon koji Uredba čini u odnosu na Hašku konvenciju. Taj otklon tiče se proširenja obveze suda da u svim slučajevima djetetu osigura mogućnost saslušanja tijekom postupka, a ne samo u slučajevima kada se dijete protivi povratku. ${ }^{27}$

Vrijednost Uredbe Bruxelles II bis u svjetlu teme rada jest da je njome Europska unija nastojala osnažiti obveze koje državama ugovornicama nameće Haška konvencija. Naime, članak 11. stavak 3. Uredbe određuje rok od šest tjedana za provedbu postupka po Haškoj konvenciji. Premda se čini da takav zahtjev ne prati odgovarajuća sankcija, barem na razini Europske unije, N. Lowe i V. Stephens upozoravaju na judikaturu Europskoga suda za ljudska prava. ${ }^{28}$ Naime, u cijelom nizu slučajeva Sud je utvrdio povredu zajamčenog konvencijskog prava

26 Praktični priručnik za primjenu Uredbe Bruxelles II.a, par. 4.1.1., dostupno na: https://op.europa.eu/en/publication-detail/-/publication/f7d39509-3f10-4ae2-b99353ac6b9f93ed (15. travnja 2021.).

27 Čl. 11/2. Uredbe u usporedbi sa čl. 13/2. Haške konvencije.

28 N. Lowe i V. Stephens ističu predmet Shaw protiv Mađarske (br. 6457/09, 26. srpnja 2011.), no ta je presuda samo jedna u nizu u kojima je Sud procjenjivao je li u postupcima relevantnim za temu rada povrijeđeno pravo na poštovanje privatnog $\mathrm{i}$ obiteljskog života. Lowe, N.; Stephens, V., Part I - A statistical analysis of applications made in 2015 under the Hague Convention of 25 October 1980 on the Civil Aspects of International Child Abduction - Global report - provisional edition, pending the completion of the French version (Preliminary Document No 11 B of October 2017), par. 11. i 45. - 47., dostupno na: https://assets.hcch.net/docs/d0b285fl-5f59-4la6-ad83-8b5cf7a784ce. pdf (15. travnja 2021.). O judikaturi Europskog suda za ljudska prava u predmetima međunarodne otmice djece vidi. više: Pavić, M.; Šimović, I.; Čulo Margaletić, A., Postupak ovrhe radi ostvarivanja osobnih odnosa roditelja i djece kao pretkazivač povrede prava iz Europske konvencije za zaštitu ljudskih prava i temeljnih sloboda, Godišnjak Akademije pravnih znanosti Hrvatske, vol. VIII, Posebni broj, 2017., str. 171 - 198 ili Šimović; Majstorović, op. cit. u bilj. 2, str. 1 - 9. 
na poštovanje privatnog i obiteljskog života upravo zbog proteka vremena. ${ }^{29}$ Medijacija u takvim slučajevima bez sumnje može predstavljati učinkovit način poštovanja roka i korisno sredstvo za prevenciju povreda prava na poštovanje privatnog i obiteljskog života stranaka uključenih u postupke međunarodne otmice djece. $^{30}$

Vjerujemo da je odraz takvoga promišljanja i sadržaj članka 55. Uredbe Bruxelles II bis, u kojem se uz načelo suradnje središnjih tijela ističe da ona poduzimaju sve potrebne korake kako bi, inter alia, olakšala postizanje sporazuma između nositelja roditeljske odgovornosti medijacijom ili drugim načinima te olakšala prekograničnu suradnju u tu svrhu. ${ }^{31}$

Novi pokušaj Europske unije da fenomenu međunarodne otmice djece pristupi sustavno i učinkovito jest Uredba Vijeća (EU) 2019/1111 od 25. lipnja 2019. o nadležnosti, priznavanju i izvršenju odluka u bračnim sporovima i u stvarima povezanima s roditeljskom odgovornošću te o međunarodnoj otmici djece (preinaka) $^{32}$, uobičajeno nazivana Uredbom Bruxelles II ter, čije će se odredbe, u dijelu relevantnom za temu ovoga rada, primjenjivati od l. kolovoza 2022. godine. Razlog usvajanja ovoga dokumenta jest zaključak europskih institucija, iznesen u točki 1. Preambule, da je "Uredba (EZ) br. 2201/2003 instrument koji dobro funkcionira i donio je važne koristi građanima, ali da bi se postojeća pravila mogla unaprijediti. Potreban je veći broj izmjena te uredbe. Radi jasnoće tu bi uredbu trebalo preinačiti." Stoga preinačena Uredba, kako se ističe u točki 2. Preambule, sadržava i odredbe kojima se dopunjuje Haška konvencija u pogledu odnosa među državama članicama: "Ovom bi Uredbom stoga trebalo

29 Lowe, N.; Stephens, V., Global trends in the operation of the 1980 Hague abduction convention, Family law quarterly, vol. 46, br. 1, 2012., str. 83. Usporedi i: https://www. echr.coe.int/Documents/FS_Child_abductions_ENG.pdf (15. travnja 2021.).

30 Sustavnosti radi, ističemo da je prema dostupnim podacima od svih zahtjeva koji su podneseni 2008. godine ovo vremensko ograničenje sustav poštovao u samo $26 \%$ zahtjeva. Tako: Lowe; Stephens, ibid., str. 84. I drugo, prema podacima dostupnim u literaturi, čini se da je nizozemsko tumačenje ovoga roka bilo sljedeće: središnje tijelo ima 42 dana za obavljanje svoje upravne funkcije, zatim sud u prvome stupnju ima 42 dana za odluku te onda stranke imaju 42 dana za žalbu. Prema: Thorpe, op. cit. u bilj. 8, str. 580. Isti autor ističe da je potvrda osnovanosti takvoga polazišta potvrđena Uredbom Bruxelles II ter. Ibid.

31 Potvrdu navedenog stajališta da se odredbom čl. 55. Uredbe Bruxelles II bis promiče korištenje medijacije u slučajevima međunarodne otmice djece pronalazimo u službenim dokumentima Europske unije - Praktični priručnik za primjenu Uredbe Bruxelles II.a, par. 7.3., op. cit. u bilj. 26.

32 Službeni list Europske unije, L 178, 2. srpnja 2019. 
pomoći u jačanju pravne sigurnosti i povećanju fleksibilnosti te osiguravanju boljeg pristupa sudskim postupcima i veće učinkovitosti takvih postupaka."

Međunarodnoj otmici djece posvećeno je poglavlje III Uredbe Bruxelles II ter (članci od 22. do 29.), pri čemu osobito ističemo vrijednost i značenje članka 25. (Alternativno rješavanje sporova), kojim se ističe: "Što je prije moguće i u bilo kojoj fazi postupka sud izravno ili, prema potrebi, uz pomoć središnjih tijela poziva stranke da razmotre jesu li spremne za sudjelovanje u posredovanju (medijaciji, op. aut.) ili drugom načinu alternativnog rješavanja sporova, osim ako je to u suprotnosti s interesima djeteta, nije prikladno u pojedinom slučaju ili bi se time neopravdano odgodio postupak."33

Ta je odredba na određeni način komplementarna točki 43. Preambule, $u$ kojoj se ističe da bi sudovi u svim predmetima koji se odnose na djecu, a posebno u slučajevima međunarodne otmice djeteta, trebali razmotriti mogućnost postizanja rješenja medijacijom i drugim prikladnim sredstvima, prema potrebi uz pomoć postojećih mreža i potpornih struktura za medijaciju u prekograničnim sporovima koji se odnose na roditeljsku odgovornost. Ipak, Vijeće, svjesno opasnosti usporavanja postupaka, koje iznimno šteti provedbi Haške konvencije kao ponajprije procesnog propisa, ističe da se zbog takvih nastojanja ne bi trebali pretjerano produljiti postupci povratka u skladu s Haškom konvencijom. ${ }^{34}$

Koliku važnost Europska unija daje promicanju i zaštiti prava djece u politikama i zakonodavstvu EU-a, pokazuje i činjenica da je Europski parlament uveo funkciju koordinatora za prava djece. Kao temeljni ciljevi koordinatora za prava djece navedeni su: pružanje pomoći građanima koji se suočavaju s međunarodnom otmicom i drugim prekograničnim obiteljskim sporovima, uspostava bliže

33 O važnosti i značenju promicanja medijacije u postupcima međunarodne otmice djece kroz odredbe Uredbe Bruxelles II ter očitovala se i akademska literatura: Bidaud, C.; Fulchiron, H.; Baret, B.; Brunerie, C.; Camuzat, A.; Delmas, C.; Fongaro, E.; Kessler, G.; Millerioux, G.; Panet-Marre, A.; Vessaud, R., A Chronicle of French Family Law: 2019, u: Brinig, M. (ur.), International Survey of Family Law 2020, Intersentia, Cambridge - Antwerp - Chicago, 2020., str. 134.

Naime, zbog konstantnih prekoračenja vremenskog roka od šest tjedana za provedbu postupaka međunarodne otmice djece (čl. 11/3. Uredbe), a ta neopravdana prekoračenja u konačnici su dovela do spomenutih mnogobrojnih povreda prava na poštovanje privatnog i obiteljskog života, utvrđenih judikaturom EKLJP-a, ovom se Uredbom ublažavaju rokovi propisani za provedbu postupaka međunarodne otmice djece te se propisuje rok od šest tjedana za postupanje u svakoj instanciji te roka od šest tjedana za izvršenje odluke - sveukupno 18 tjedana (čl. 24. i čl. 28.). 
suradnje sa sudskim i administrativnim tijelima država članica te promicanje medijacije u prekograničnim obiteljskim slučajevima. ${ }^{35}$

\subsection{Nacionalni propisi}

I u hrvatskom je zakonodavstvu potreba za dodatnim uređenjem pitanja protupravnog odvođenja i zadržavanja djece davno prepoznata. Kako je i primjereno, zakonodavac određuje tri smjera djelovanja: međunarodnoprivatnopravni, kaznenopravni i obiteljskopravni, jer se samo sustavnim i složenim pristupom može pridonijeti rješavanju građanskopravnih otmica djece.

\subsection{Zakon o provedbi Konvencije o građanskopravnim vidovima međunarodne otmice djece}

Inicijativa za dodatnim uređenjem pitanja međunarodne otmice djece počela je prije desetak godina prijedlogom Zakona o izmjeni i dopunama Obiteljskog zakona. ${ }^{36}$ Držalo se da će zakonska promjena olakšati ostvarenje četiriju temeljnih ciljeva. ${ }^{37}$ Prvo, definiranje jednog središnjeg tijela za zaprimanje zahtjeva na temelju Haške konvencije umjesto dotadašnjih dvaju tijela ${ }^{38}$, čime bi se izbjeglo udvostručavanje nadležnosti i skratilo vrijeme za postupanje po

35 Vidi: https://www.europarl.europa.eu/at-your-service/hr/be-heard/coordinator-onchildren-rights (15. travnja 2021.).

36 Ministarstvo pravosuđa, kao predlagatelj propisa, zalagalo se da se u tada važećem propisu promijeni naziv poglavlja 4. u glavi IV te da glasi "Postupak po Haškoj konvenciji o građansko-pravnim aspektima međunarodne otmice djece iz 1980. godine" te da se iza članka 332. dodaju članci 332. a do 332. j. O tome prema: Majstorović, I., Harmonizacija i unifikacija europskoga obiteljskog prava, Pravni fakultet u Zagrebu, Zagreb, 2009., str. 120 - 122.

37 Ibid

38 Nakon notifikacije o sukcesiji uloga središnjeg tijela bila je podijeljena između dvaju ministarstava - Ministarstva zdravstva i socijalne skrbi te Ministarstva pravosuđa - što je izazvalo intervenciju Stalnog ureda Haške konferencije upućene (tadašnjem) Ministarstvu vanjskih poslova o nemogućnosti istodobnog djelovanja dvaju tijela kao središnjih izvršnih organa. Usporedi: Jakovac-Lozić; Klarin, op. cit. u bilj. 8, str. 82. Stoga je ministarstvo nadležno za poslove socijalne skrbi (sada: Ministarstvo rada, mirovinskoga sustava, obitelji i socijalne politike) određeno kao središnje tijelo, a Ministarstvo pravosuđa kao tijelo zaduženo za pomoć središnjem tijelu (The authority designated to serve the Central Authority). Vidi: http://hcch.e-vision.nl/ index_en.php?act=authorities.details\&aid=81 (15. travnja 2021.). 
zahtjevu za povrat djeteta, koji je žurne naravi. Drugo, definiranje procesnih ovlasti središnjeg tijela te položaja i uloge centra za socijalnu skrb i uloge policije u navedenim postupcima te određivanje preciznih rokova za postupanje državnih tijela i sudova. Treće, određivanje jasnih i kratkih rokova za postupanje u povodu zahtjeva za vraćanjem protupravno oduzetog ili zadržanog djeteta. I četvrto, propisivanje koncentrirane nadležnosti sudova na način da se odredi samo nekoliko sudova koji će biti nadležni za postupanje u tim predmetima. Svrhu zakonodavne inicijative i tada smo smatrali opravdanom, no kritizirali smo zamisao njezina tehničkog ostvarenja te se zalagali za usvajanje posebnog provedbenog propisa. ${ }^{39}$

Nakon višekratnog osnivanja radnih skupina za izradu nacrta zakona taj je cilj i ostvaren 2018. godine usvajanjem Zakona o provedbi Konvencije o građanskopravnim vidovima međunarodne otmice djece. ${ }^{40}$ Tim Zakonom, koji je stupio na snagu 1. siječnja 2019., uređuju se nadležnost i ovlasti tijela te postupak u vezi sa zahtjevima koji se podnose u Republici Hrvatskoj na temelju odredaba Konvencije o građanskopravnim vidovima međunarodne otmice djece. Cilj je propisa usklađen s idejom same Haške konvencije te se definira na sljedeći način: “osiguranje žurnog povratka protupravno odvedenog ili zadržanog djeteta te ostvarivanje kontakata djeteta s odvojenim roditeljem i s drugim osobama kojima to pravo pripada, vodeći računa o poticanju roditeljskog sporazumijevanja te zaštiti najboljeg interesa i dobrobiti djeteta."4l

Bitno je istaknuti i da je ovim propisom određena koncentracija nadležnosti s ciljem povećanja ekspeditivnosti i uspješnosti provedbe postupaka međunarodne otmice djece. Naime, sukladno članku 14., o zahtjevu za povratak protupravno odvedenog ili zadržanog djeteta odlučuje Općinski građanski sud u Zagrebu, a o žalbama protiv odluka toga suda odlučuje Županijski sud u Zagrebu, što bi u konačnici trebalo dovesti do specijalizacije sudaca te ujednačavanja sudske prakse. Stroža procesna pravila (čl. 16. - 19.) trebala bi predstavljati dodatni osigurač provedbe postupaka međunarodne otmice djece unutar instruktivnog roka od šest tjedana, što je novi korak u smjeru prevencije povreda prava na poštovanje privatnog i obiteljskog života stranaka uključenih u navedene postupke. Velika je vrijednost Zakona i u tome da je izrijekom uredio pitanja provođenja obiteljske medijacije u slučajevima međunarodne građanskopravne otmice, o čemu više infra.

\footnotetext{
Majstorović, op. cit. u bilj. 36, str. 122.

40 Narodne novine, br. 99/2018.

41 Čl. 3. Zakona o provedbi Konvencije o građanskopravnim vidovima međunarodne otmice djece.
} 
2.4.2. Zakon o provedbi Uredbe Vijeća (EZ) br. 2201/2003 o području nadležnosti, priznanja i izvršenja sudskih odluka u bračnim sporovima i u stvarima povezanim s roditeljskom skrbi

Republika Hrvatska je nakon stupanja u punopravno članstvo Europske unije ovim provedbenim Zakonom ${ }^{42}$ dodatno propisala središnje tijelo za provedbu Uredbe Bruxelles II bis, a to je ministarstvo nadležno za poslove socijalne skrbi, koje u ostvarenju ciljeva Uredbe surađuje s tijelima državne uprave nadležnima za poslove pravosuđa, unutarnjih poslova, vanjskih i europskih poslova te $s$ drugim državnim tijelima. ${ }^{43} \mathrm{Za}$ temu ovoga rada valja istaknuti da je zakonodavac, propisujući djelokrug Središnjeg tijela osobito, inter alia, istaknuo zaštitu dobrobiti i interesa djeteta te poticanje mirnog rješavanja sporova. ${ }^{44}$

\subsubsection{Kazneni zakon}

Kazneni zakon ${ }^{45}$ predviđa odgovornost za djelo oduzimanja djeteta, regulirano člankom 174. Naime, tko dijete oduzme od roditelja, posvojitelja, skrbnika, druge osobe ili ustanove kojoj je ono povjereno, protupravno ga zadrži ili mu onemogućava da živi s osobom ili u ustanovi kojoj je povjereno, kaznit će se kaznom zatvora od šest mjeseci do pet godina. Ako je pak ovo kazneno djelo počinjeno s ciljem da se dijete trajno zadrži ili ako je zbog počinjenja kaznenog djela dijete napustilo područje Republike Hrvatske ili je teže ugroženo njegovo zdravlje, odgoj, školovanje ili je pak na drugi način teško ugrožena dobrobit djeteta, predviđena je kazna zatvora od jedne do deset godina.

Valja dodati da ako djelo počini roditelj (ili posvojitelj), a upravo je tzv. roditeljska otmica u praksi najčešći slučaj, propisana je zatvorska kazna do tri godine. Bitno je napomenuti da će se počinitelj kazniti i za pokušaj ovog kaznenog djela, a onaj počinitelj koji vrati dijete prije započinjanja kaznenog postupka može se osloboditi kazne. Također, ako roditelj ili posvojitelj ovo djelo počini s ciljem da trajno zadrži dijete ili na način da dijete napusti državni teritorij, propisana je kazna od šest mjeseci do pet godina. Ako je pak kaznenim djelom prouzročena smrt djeteta, počinitelj će se kazniti kaznom zatvora od tri do petnaest godina.

42 Narodne novine, br. 127/2013.

43 Čl. 3. Zakona o provedbi Uredbe Vijeća (EZ) br. 2201/2003.

44 Članak 4. stavci 4. i 9. Zakona o provedbi Uredbe Vijeća (EZ) br. 2201/2003.

45 Narodne novine, br. 125/2011, 144/2012, 56/2015, 61/2015, 101/2017, 118/2018, 126/2019. 
Izloženim zakonskim uređenjem hrvatski je zakonodavac implementirao zamisao Haške konferencije za međunarodno privatno pravo o potrebi kaznenog sankcioniranja počinitelja međunarodne otmice djece s ciljem preventivnog djelovanja, tj. odvraćanja roditelja od protupravnog odvođenja ili zadržavanja djeteta zbog činjenice da se time izlažu mogućnosti kaznenog progona. ${ }^{46}$

\subsubsection{Obiteljski zakon}

Obiteljski zakon ${ }^{47}$ pitanja otmice djece uređuje u nacionalnim okvirima, dakle u situacijama koje nemaju međunarodno obilježje, no sve se veća pozornost u sustavu posvećuje i rješavanju fenomena međunarodnih otmica djece. Štoviše, za neka se rješenja uvedena 2014., odnosno 2015. godine može pretpostaviti da su odraz promišljanja upravo o Haškoj konvenciji o građanskopravnim vidovima međunarodne otmice djece, tj. o jednom od osnovnih ciljeva te Konvencije potrebi prevencije slučajeva međunarodne otmice djece na nacionalnoj razini država stranaka. Riječ je o članku 418. o mjerama kojima se osigurava provedba odluke o ostvarivanju osobnih odnosa djeteta s roditeljem te osobito o članku 419. o mjerama kojima se osigurava povratak djeteta, koje su relevantne za temu ovoga rada zato što bi odgovarajuća primjena navedenih odredaba na nacionalnoj razini mogla prevenirati nezakonito odvođenje ili zadržavanje djeteta od strane bilo kojeg od roditelja i na taj način ostvariti jedan od ciljeva Haške konvencije, kao i Konvencije o pravima djeteta (čl. 11.).

Naime, na tragu stajališta da domaće pravo treba uključivati odredbe koje sprječavaju i odvraćaju od odvođenja djece ${ }^{48}$, sukladno članku 419. Obiteljskog zakona, sud može u postupku u kojem se odlučuje o ostvarivanju osobnih odnosa djeteta s roditeljem odrediti jednu mjeru ili više mjera kojima se osigurava

46 O prednostima, ali i nedostacima kaznenog sankcioniranja međunarodne otmice djece podrobnije u službenom dokumentu Haške konferencije za međunarodno privatno pravo - Guide to Good Practice under the Hague Convention of 25 October 1980 on the Civil Aspects of International Child Abduction - Part III - Preventive Measures, The Hague Conference on Private International Law, Hague, 2005., str. 13 - 14 i 30 - 31, dostupno na: https://www.hcch.net/en/publications-andstudies/details4/?pid=3639 (15. travnja 2021.); Khazova; Mezmur, op. cit. u bilj. 7, str. $341-342$.

47 Narodne novine, br. 103/2015, 98/2019, 49/2020.

48 Vidi dokument Haške konferencije naveden u bilj. 46, str. 16 - 17. Vrijedi ponovno istaknuti da je prevencija međunarodne otmice djece jedan od ciljeva koji se nastoje postići ne samo nacionalnim pravnim dokumentima (primjerice, Obiteljskim zakonom), već i u radu prikazanim međunarodnim globalnim i regionalnim dokumentima. Vidi bilj. 7, 11 i 12 ovog rada. 
povratak djeteta ili zaprječuje protupravno odvođenje djeteta od strane roditelja koji ima pravo ostvarivati osobne odnose s djetetom, i to:

1. odrediti obvezu predaje putovnice roditelja koji ima pravo ostvarivati osobne odnose s djetetom za vrijeme ostvarivanja osobnih odnosa s djetetom sudu koji je mjeru odredio

2. odrediti obvezu polaganja jamstva u novcu od strane roditelja koji ima pravo ostvarivati osobne odnose s djetetom

3. odrediti zabranu otuđenja ili opterećenja imovinskih prava roditelju koji ima pravo ostvarivati osobne odnose s djetetom uz zabilježbu i upis zabrane $\mathrm{u}$ javne upisnike

4. odrediti obvezu roditelja koji ima pravo ostvarivati osobne odnose da se redovito javlja zajedno s djetetom ovlaštenom tijelu kao što je centar za socijalnu skrb u mjestu gdje se osobni odnosi ostvaruju

5. odrediti mjesto gdje se osobni odnosi imaju ostvarivati i

6. zabraniti odlazak djeteta iz države u kojoj se osobni odnosi imaju ostvarivati te odrediti registraciju zabrane u državnom ili prekograničnom informacijskom sustavu. ${ }^{49}$

Sukladno članku 322. Obiteljskog zakona prije pokretanja "ostalih sudskih postupaka o ostvarivanju roditeljske skrbi i osobnih odnosa s djetetom”, što je dodatno razrađeno člankom 329. istog Zakona ${ }^{50}$, potrebno je provesti postupak obveznog savjetovanja koji se provodi pri centru za socijalnu skrb, što može biti otegotna okolnost iz perspektive vremenskih zahtjeva koje postavlja Uredba Bruxelles II bis. S druge strane, obvezno savjetovanje je i prilika da roditelji na sporazumni način pokušaju riješiti sporna pitanja te dobiju informacije o pravnim i psihosocijalnim posljedicama svojih postupaka, što je u skladu sa svim prikazanim dokumentima. Obvezno savjetovanje je i još jedna prilika za informiranje o mogućnosti provedbe postupka obiteljske medijacije ako se sporazum ne postigne $\mathrm{u}$ obveznom savjetovanju. Naravno, to podrazumijeva

49 Pojedini autori ističu da citirana odredba čl. 419. st. 1. t. 6. Obiteljskog zakona sadržava najkorisniji mehanizam za prevenciju nezakonitog odvođenja djeteta. Vidi: Župan, M.; Hoško, T., Operation of the Hague 1980. Child Abduction Convention in Croatia, u: Župan, M. (ur.), Private International Law in the Jurisprudence of European Courts - Family at Focus, Faculty of Law Osijek, Josip Juraj Strossmayer University of Osijek, Osijek, 2015., str. 231.

50 O problemu provođenja obveznog savjetovanja prije pokretanja izvanparničnih sudskih postupaka za povratak djece prema Haškoj konvenciji podrobnije u: Šimović; Majstorović, op. cit. u bilj. 2, str. 6. U tome se radu autori zalažu "da se težište mirnog rješavanja prijepora usmjeri na obiteljsku medijaciju, kako se sudski postupak ne bi dodatno usporio uslijed provedbe postupka obveznog savjetovanja”. Ibid. 
da se postupak obveznog savjetovanja provodi od strane stručnjaka koji su educirani za rad s roditeljima u području otmice djece i informirani o mogućnosti provedbe obiteljske medijacije u slučajevima otmice djece. Sam postupak obiteljske medijacije u takvim slučajevima je isto vremenski ograničen, o čemu će kasnije biti više riječi.

Pitanje usklađivanja dvaju zahtjeva, onoga za provedbu postupka u što kraćem roku koji je propisan i nužan te onoga za poticanjem sporazumnog rješavanja sporova o tome gdje će dijete živjeti i kako će se ostvarivati osobni odnosi s roditeljima mogu djelovati suprotstavljeno iako oni to ne bi trebali biti. S obzirom na to da se u točki 42. Preambule Bruxelles II bis ističe rok od šest tjedana u kojem bi sudovi svih stupnjeva trebali donijeti odluku u postupcima povratka djeteta, osim ako je to nemoguće zbog iznimnih okolnosti, te da se primjena načina alternativnog rješavanja sporova ne bi sama po sebi trebala smatrati iznimnom okolnosti zbog koje se smije prekoračiti vremenski okvir, potrebno je žurno funkcioniranje svih institucija. Poduzimanje najboljih intervencija u najkraćem roku važno je zbog pravnih, psiholoških i socijalnih razloga koji su u ovakvim slučajevima međupovezani. Dakle, riječ je o postupku u kojem je potrebno aktivno i usklađeno djelovanje različitih stručnjaka, onih iz područja prava i iz psihosocijalnog područja, kao i obiteljskih medijatora koji su dodatno educirani i posjeduju napredna znanja i vještine potrebne za djelovanje u ovim kompleksnim situacijama.

$\mathrm{U}$ odnosu na pravne osnove ovrhe, valja istaknuti da se onima navedenim u članku 513. Obiteljskog zakona svakako može pridodati i rješenje suda kojim se nalaže povratak djeteta po Haškoj konvenciji ili Uredbi Bruxelles II bis, premda ono nije izrijekom navedeno kao ovršna isprava u citiranom članku Obiteljskog zakona, što je značajan propust zakonodavca. Navedeni zakonski propust može se premostiti primjenom opće procesne odredbe članka 346. Obiteljskog zakona o supsidijarnoj primjeni "zakona kojim se uređuje prisilno ostvarenje tražbina". Naime, rješenje suda kojim se nalaže povratak djeteta po Haškoj konvenciji ili Uredbi Bruxelles II bis sigurno ulazi u krug ovršnih isprava na temelju kojeg se može odrediti i prisilno provesti ispunjenje tražbine na neko činjenje - povratak djeteta u državu u kojoj je imalo uobičajeno boravište neposredno prije nezakonitog odvođenja ili zadržavanja, pozivom na podrednu primjenu odredaba Ovršnog zakona. ${ }^{51} \mathrm{U}$ odnosu pak na sredstva ovrhe sud će prema članku 514. Obiteljskog zakona, uzimajući u obzir okolnosti slučaja, odrediti ovrhu izrica-

${ }_{51}$ Usporedi članak 346. Obiteljskog zakona u vezi s člancima 23. do 25. Ovršnog zakona, Ovršni zakon, Narodne novine, br. 112/2012, 25/2013, 93/2014, 55/2016, 73/2017, 131/2020. 
njem i provođenjem: novčane kazne do trideset tisuća kuna, zatvorske kazne u trajanju od jednog dana do šest mjeseci ili prisilnog oduzimanja i predaje djeteta.

Bitno je, naime, istaknuti da se postupak ovrhe za povratak protupravno odvedenog ili zadržanog djeteta provodi prema pravilima važećeg Obiteljskog zakona, podredno Ovršnog zakona, što je i utvrđeno odredbom članka 26. Zakona o provedbi Konvencije o građanskopravnim vidovima međunarodne otmice djece. Time se potvrđuje teza zauzeta u pravnoj teoriji prema kojoj postupak ovrhe za povratak protupravno odvedenog ili zadržanog djeteta nije reguliran Haškom konvencijom, već nacionalnim pravom pojedine države članice Vijeća Europe u kojoj je proveden postupak za povratak djeteta i donesena ovršna isprava. ${ }^{52}$

Kako bi se pak prisilno oduzimanje i predaja djeteta, kao ultima ratio, proveli na način koji odgovara suvremenim standardima zaštite prava djeteta te poštovanja prava roditelja i ostalih članova obitelji, sukladno članku 516. Obiteljskog zakona, ministar nadležan za poslove pravosuđa, uz prethodnu suglasnost ministra nadležnog za unutarnje poslove i ministra nadležnog za socijalnu skrb, propisao je podzakonskim aktom pojedinosti postupka, uz ključno načelo zaštite djeteta te suradnje svih uključenih državnih tijela, koji je tema u nastavku rada.

\subsubsection{Pravilnik o načinu postupanja i suradnje suca, stručnog radnika centra za socijalnu skrb i policijskog službenika za mladež prilikom prisilnog oduzimanja i predaje djeteta}

Nakon pravomoćnosti i ovršnosti rješenja suda, kojim se nalaže povratak djeteta po Haškoj konvenciji ili Uredbi Bruxelles II bis, prisilno oduzimanje i predaju djeteta obavljaju u suradnji sud i centar za socijalnu skrb na način da zaštite dijete u najvećoj mogućoj mjeri, uz pomoć policije, odnosno policijskog službenika za mladež. Pojedinosti ovog postupka uređene su posebnim provedbenim propisom - Pravilnikom o načinu postupanja i suradnje suca, stručnog radnika centra za socijalnu skrb i policijskog službenika za mladež prilikom prisilnog oduzimanja i predaje djeteta. ${ }^{53}$

U odnosu na postupanja sudova valja istaknuti dvije norme. Prvo, člankom 4. određuje se da je cilj sudskog postupanja učinkovita provedba ovrhe radi

52 Tako primjerice: McEleavy, P., The European Court of Human Rights and the Hague Child Abduction Convention: Prioritising Return or Reflection?, Netherlands International Law Review, vol. 62, 2015., br. 3, str. 388; Kruger, T., International Child Abduction, u: Ippolito, F. (ur.), Migrant children: Challenges for public and private international law, Editoriale Scientifica, 2016., str. 106.

53 Narodne novine, br. 48/2016, 112/2018. 
prisilnog oduzimanja i predaje djeteta, uz ograničenje da se ovršne radnje mogu poduzimati samo ako je to u skladu s temeljnim načelom o prvenstvenoj zaštiti dobrobiti i prava djeteta. Navedeno je rješenje potvrda prihvaćanja kriterija najboljeg interesa djeteta kao ključnog u odlučivanju o svim pitanjima koja se na djecu odnose. Druga norma koju valja pozdraviti jest odredba članka 5. koji zahtijeva da je sud dužan radnje u postupku poduzimati žurno, u koordinaciji s ostalim tijelima i osobama u tim tijelima koji sudjeluju u provedbi ovrhe radi prisilnog oduzimanja i predaje djeteta. ${ }^{54}$

U odnosu na djelovanje centra za socijalnu skrb Pravilnikom se ističe da centar pruža savjetodavnu potporu u provedbi postupka ovrhe radi prisilnog oduzimanja i predaje djeteta te poduzima nužne mjere pomoći i podrške djetetu i drugim osobama koje sudjeluju u provedbi ovrhe radi prisilnog oduzimanja i predaje djeteta. ${ }^{55}$

Načelo koje je kao ključno ponovljeno ovim Pravilnikom jest načelo žurnosti, koje je bez sumnje presudno u provedbi ovrhe radi prisilnog oduzimanja i predaje djeteta ${ }^{56}$, čemu se pridodaju sljedeća načela: načelo tajnosti i zaštite osobnih podataka; načelo hijerarhije i subordinacije; načelo samoprocjene; načelo odgovornosti i učinkovitosti te načelo neposredne i usmene komunikacije. ${ }^{57}$

54 Navedena koordinacija, sukladno članku 6. Pravilnika, obuhvaća:

a) poduzimanje potrebnih radnji u svrhu prethodne provjere jesu li ispunjeni uvjeti za uredovanje radi prisilnog oduzimanja i predaje djeteta

b) povezivanje tijela i osoba u tim tijelima koji sudjeluju u postupku ovrhe radi prisilnog oduzimanja i predaje djeteta

c) usuglašavanje o vremenu i mjestu uredovanja

d) održavanje koordinacijskog sastanka prije samog provođenja postupka radi izravne međusobne razmjene informacija bitnih za uspješnu realizaciju ovršnog postupka na kojem će se usuglasiti pojedinačne zadaće tijela i osoba koja sudjeluju u postupku, razmotriti raspoložive informacije o djetetovu fizičkom i psihičkom stanju, razmotriti je li potrebna nazočnost doktora medicine odnosno ekipe hitne medicinske pomoći i drugo

e) druge aktivnosti kojima se postiže sklad u postupanju u provedbi ovrhe radi prisilnog oduzimanja i predaje djeteta.

55 Čl. 13. Pravilnika.

56 Usporedi: Šimović; Majstorović, op. cit. u bilj. 2, str. 1 - 9.

57 Čl. 20. Pravilnika. 


\section{OBITELJSKA MEDIJACIJA U SLUČAJEVIMA MEĐUNARODNE OTMICE DJECE}

\subsection{Teorijsko utemeljenje i osnovni zahtjevi}

Analiza pravnoga okvira jasno upućuje na to da je obiteljska medijacija dugo bila neprepoznat instrument rješavanja protupravnog odvođenja i zadržavanja djece i na međunarodnoj, i na nacionalnoj razini. Riječima M. Thorpea, "sasvim je jasno da tvorci Haške konvencije nisu nikad promišljali o medijaciji”. ${ }^{58}$ Međutim, činjenica jest da je obveza svih država ugovornica Haške konvencije poduzeti "sve odgovarajuće mjere da na svojem državnom području osiguraju ostvarivanje ciljeva Konvencije" te u tu svrhu primjenjuju "najbrže moguće postupke”. ${ }^{59}$ Među ostalim, za temu ovoga rada važan je članak 7 . Haške konvencije, koji propisuje da središnja tijela, neposredno ili putem drugih, poduzimaju sve odgovarajuće mjere, inter alia, za "lakše postizanje sporazumnog rješenja". Obiteljska medijacija bez sumnje je jedan od najprimjerenijih načina postizanja takvog rješenja. ${ }^{60}$

Danas je stoga primjena obiteljske medijacije i ostalih oblika alternativnog rješavanja sukoba i sporova u slučajevima međunarodne otmice djece preporučena od strane svih tijela koja se bave provedbom Haške konvencije i svim ranije prikazanim provedbenim propisima. Tako je Stalni ured Haške konferencije za međunarodno privatno pravo 2012. godine objavio i poseban Vodič k dobroj praksi prema Haškoj konvenciji od 25. listopada 1980. o građanskopravnim vidovima međunarodne otmice djece: Medijacija ${ }^{61}$ Vodič donosi temeljna načela provedbe procesa medijacije u ovakvim slučajevima:

58 Thorpe, op. cit. bilj. 8, str. 577.

59 Čl. 2. Haške konvencije. Zanimljivo je primijetiti da je raniji službeni prijevod engleskog sklopa "the most expeditious procedures available" bio "najuspješniji raspoloživi postupci”. Danas je pojam "najuspješniji”, jezično opravdano, zamijenjen pojmom "najbrži mogući”. Sadržajno, međutim, ne bismo ni raniji prijevod smatrali neprimjerenim jer upravo pogađa bit postupaka u predmetima međunarodne otmice djece. Naime, premda treba inzistirati na žurnosti, valja naći rješenje koje je za dijete najbolje, pa je to samim time i najuspješnije rješenje.

60 Potencijal obiteljske medijacije prepoznat je u suvremeno doba u brojnim dokumentima. Usporedi, primjerice, čl. 31. Konvencije o nadležnosti, mjerodavnom pravu, priznanju, ovrsi i suradnji u odnosu na roditeljsku odgovornost i o mjerama za zaštitu djece (Narodne novine, Međunarodni ugovori, br. 5/2009.) ili pak supra spomenut čl. 13. Europske konvencije o ostvarivanju dječjih prava.

${ }_{61}$ Guide to Good Practice under the Hague Convention of 25 October 1980 on the Civil Aspects of International Child Abduction - Mediation, op. cit. u bilj. 4. 
1. Poduzimanje primjerenih koraka kako bi se strane ohrabrilo i potaknulo na sporazum o spornim pitanjima.

2. Osiguranje da nitko od sudionika ne dođe u nepovoljniji položaj zbog sudjelovanja u medijaciji.

3. Medijacija i drugi postupci koji imaju cilj postizanje sporazuma u obiteljskim sukobima trebaju se smatrati komplementarnim pravnim postupcima, a ne njihovom zamjenom. Dostupnost sudskih postupaka ne smije biti ograničena.

4. Medijacija u obiteljskim sukobima s međunarodnim elementom treba uzeti u obzir nacionalne i međunacionalne propise kako bi postignuti sporazum bio u skladu s relevantnim zakonodavstvom.

5. Pravni postupci trebali bi uvažiti sporazume postignute u medijaciji i dati im pravni značaj.

Navedene međunarodne standarde slijedi i nacionalni propis. Naime, članak 12. Zakona o provedbi Konvencije o građanskopravnim vidovima međunarodne otmice djece izrijekom predviđa mogućnost provedbe medijacijskog postupka. Sukladno ovoj odredbi, kad zaprimi zahtjev iz druge države ugovornice, Središnje tijelo ili sud obavijestit će stranke o mogućnosti mirnog rješenja spora u postupku obiteljske medijacije. Pritom je važno naglasiti da postupak obiteljske medijacije ne utječe na pokretanje postupka pred sudom, ona se, naime, može provoditi neovisno o sudskom postupku, prije pokretanja sudskog postupka, za vrijeme njegova trajanja ili nakon dovršetka sudskog postupka. ${ }^{62}$

Obiteljsku medijaciju trebaju provoditi obiteljski medijatori osposobljeni za prekogranične sporove upisani u registar obiteljskih medijatora koji vodi ministarstvo nadležno za poslove socijalne skrbi. ${ }^{63}$ Obavijest o pokretanju postupka obiteljske medijacije medijator dostavlja Središnjem tijelu i sudu, koji može zastati

62 Čl. 334. st. 1. Obiteljskog zakona.

63 Registar obiteljskih medijatora dostupan je na: https://mrosp.gov.hr/UserDocsImages/dokumenti/MDOMSP\%20dokumenti/Registar\%20obiteljskih\%20medijatora\%202019-10.11.pdf (15. travnja 2021.), no nažalost nije naznačeno koji su medijatori dodatno educirani za provedbu obiteljske medijacije u slučajevima međunarodne otmice djece. Osim toga, analiza komparativnih rješenja upućuje na različite primjere organizacije medijacijske aktivnosti. U državama zapadne Europe, koje njeguju dužu tradiciju medijacije, profilirale su se i brojne nedržavne inicijative, kao što su Reunite international child abduction centre (Reunite) u Ujedinjenom Kraljevstvu, Internationales Mediationszentrum für Familienkonflikte und Kindesentführung (MiKK) u Njemačkoj ili pak Centrum Internationale Kinderontvoering u Nizozemskoj. U svim tim organizacijama medijaciju u slučajevima međunarodne otmice djece provode medijatori dodatno educirani za rad u tom području. 
s postupkom, a može i odrediti rok u kojem treba provesti postupak medijacije. Ako stranke postignu sporazum, o tome se obavještavaju Središnje tijelo i sud, koji sukladno članku 12. stavku 12. provjerava je li takav sporazum u skladu s najboljim interesom djeteta te je li protivan pravnom poretku Republike Hrvatske ili javnom interesu. Unatoč saznanjima autora da je u manjem broju slučajeva u Hrvatskoj provedena medijacija u slučajevima međunarodne otmice djece, o tome nažalost još nije uspostavljena sustavna evidencija.

Dakle, pravnim normama prihvaćena su teorijska određenja i razumijevanje medijacije kao dobrovoljnog, strukturiranog postupka u kojem medijator kao neutralna i nepristrana strana ima cilj korištenjem komunikacijskih i pregovaračkih tehnika potaknuti sudionike na donošenje obostrano prihvatljivih sporazuma o spornim pitanjima. Na taj se način omogućava stranama u sukobu da preuzmu odgovornost za pronalaženje rješenja spornih pitanja te da samostalno donesu odluke koje se tiču načina njihova života i života njihove djece. ${ }^{64}$ Upravo donošenje odluka od strane onih koji trebaju živjeti te odluke te s tim povezana veća vjerojatnost da će se donesene odluke i poštovati prednosti su obiteljske medijacije. ${ }^{65}$

Sporovi koji proizlaze iz otmice djece s međunarodnim karakterom imaju, kao što smo već spomenuli, složenu isprepletenost pravnih, psiholoških i socijalnih pitanja, odnosno ne treba ih promatrati kao isključivo pravno pitanje upravo zbog visoke razine sukoba, nepovjerenja i složene dinamike odnosa među članovima obitelji te psihosocijalnih uzroka i posljedica takvog čina. Provedba postupka obiteljske medijacije u ovim je slučajevima specifična i kompleksna te se razlikuje po načinu provedbe samog postupka od obiteljske medijacije $u$ drugim obiteljskim sukobima, pa i razvodu braka. Zbog toga potrebno je dodatno obrazovanje obiteljskih medijatora specifično za međunarodnu obiteljsku medijaciju. Sve europske države zahtijevaju da su medijatori kompetentni upravljati sporom (to handle the dispute) pred njima. Postoji, međutim, velika razlika u pristupu, osobito u odnosu na pravila ponašanja, mehanizme kontrole kvalitete i edukacije. ${ }^{66}$ Sadržaji dodatne edukacije trebali bi uključivati: pravne aspekte

64 Usporedi: Guide to Good Practice under the Hague Convention of 25 October 1980 on the Civil Aspects of International Child Abduction - Mediation, op. cit. u bilj. 4, par. 33 .

65 Tako Roberts, M., Mediation in family disputes, Wildwood House Ltd., Aldershot, 1988., navedeno prema Sladović Franz, B., Obilježja obiteljske medijacije, Ljetopis socijalnog rada, vol. 12, br. 2, 2005., str. $301-320$.

66 Riveros, C.; Coester-Waltjen, D., Alternative dispute resolution in family disputes in Europe and Chile: Mediation, Direito GV Law review, vol. 15, no. 1, 2019., str. 7. U brojnim se europskim državama provode različite edukacije, različite duljine traja- 
međunarodnih obiteljskih sporova koji uključuju roditelje i djecu, posebice pitanja Haške konvencije; kulturne različitosti i uvažavanje kulturnih različitosti; specifične okolnosti života binacionalnih i multinacionalnih obitelji i obitelji migranata, kao i posebne intervencije medijatora u međunarodnim slučajevima u kojima je potrebno djelovati brzo s obzirom na vremensko ograničenje provedbe intervencija. ${ }^{67}$

Kompleksnost provedbe proizlazi kako iz visoke razine sukoba i nepovjerenja među roditeljima tako i iz vremenskog okvira provedbe o kojoj je već bilo riječi, različitih pravnih sustava koji su uključeni u rješavanje spora, različite kulture sudionika, nerijetko različitih jezika kojima sudionici govore, što sve ima utjecaj na način provedbe procesa medijacije.

Razlike postoje i u načinu na koji se roditelji informiraju o mogućnostima obiteljske medijacije. ${ }^{68}$ Prema iskustvima zemalja u kojima se provodi obiteljska medijacija u tim slučajevima, informacije se najčešće dobiju od odvjetnika, sudaca i stručnjaka zaposlenih u središnjim tijelima provedbe Haške konvencije, službama socijalne skrbi, uredima međunarodnih udruženja koja pružaju usluge medijacije, a rjeđe informacije mogu dobiti i od ministarstva pravosuđa. Iako je medijacija navedena u različitim pravnim aktima, na temelju iskustva provedbe medijacije, može se reći da je prisutan i nedostatak informacija o obiteljskoj medijaciji te je tim važnija uloga odvjetnika ${ }^{69}$, sudaca, službenika središnjih tijela provedbe da pružaju informacije o mogućnosti obiteljske medijacije od pokretanja postupka te tijekom cijelog postupka.

Obiteljska medijacija treba biti ponuđena roditeljima kao mogućnost jer često iz perspektive roditelja predstavlja zadnju šansu da se postigne dogovor. Iskustva su pokazala da, iako roditelji ne postignu dogovor, samo sudjelovanje u medijaciji može imati pozitivan učinak na njihovu daljnju komunikaciju. Pružanje informacija tijekom cijelog postupka važno je jer se i motivacija roditelja za

nja, a socijalna radnica - suautorica ovog rada - jedna je od triju hrvatskih medijatora posebno osposobljenih za provedbu međunarodne obiteljske medijacije.

67 Paul, C. C.; Walker, J., A case for mediation: Family mediation in international child custody conflicts, World Arbitration \& Mediation Review, vol. 1, br. 4, 2007., str. 589 - 594. Prikaz obrazovnih programa za medijatore u domaćem i međunarodnom kontekstu te u području međunarodne obiteljske medijacije mogu se naći u radu Branica, V., Obrazovanje obiteljskih medijatora u hrvatskom i medunarodnom kontekstu, Ljetopis socijalnog rada, vol. 27, br. 2, 2020., str. $231-254$.

O tome prema: Kiesewetter, S.; Paul, C. C., Cross-Border Family Mediation, Wolfgang Metzner Verlag, Frankfurt, 2009. 
sudjelovanjem može mijenjati. Također, praktična prednost obiteljske medijacije ogleda se u mogućnosti pregovaranja i dogovaranja o različitim spornim pitanjima (npr. kontakti s drugim članovima obitelji, obrazovanje djeteta, način upoznavanja kulture i jezika drugog roditelja), a ne samo o pravnim pitanjima poput na kojoj će adresi dijete živjeti, hoće li ostati s roditeljem koji ga je protupravno odveo odnosno zadržao ili će se vratiti u državu u kojoj je živjelo prije otmice. ${ }^{70}$

\subsection{Provedba medijacijskog postupka}

Medijaciju bi, prema idealnom i preporučenom standardu, trebala provoditi dva obiteljska medijatora različitog spola i djelovati kao suvoditeljski par, obrazovan za slučajeve međunarodne obiteljske medijacije. Medijatori bi trebali biti iz zemlje iz koje je svaki od roditelja (tako svaki roditelj ima jednu osobu koja govori isti jezik i poznaje kulturu i običaje) te bi trebali biti različitih profesija, jedan medijator pravnik, a drugi pomažuće struke (npr. psiholog, socijalni radnik).

Kada se postupak obiteljske medijacije provodi nakon što je dijete već oteto, a pravni postupci pokrenuti, postupak bi trebalo provesti što prije moguće. Datum provedbe medijacije može se povezati s datumom sudskog ročišta, odnosno medijacija bi se trebala odvijati nekoliko dana ranije. Na taj se način smanjuju troškovi prijevoza i smještaja te se otvara mogućnost da se sporazum postignut na medijaciji potvrdi na sudu. Posebnost primjene obiteljske medijacije u slučajevima međunarodne otmice djece koja se tiče prethodno navedenog vremenskog okvira jest provođenje postupka medijacije u blok-susretima (dva ili tri uzastopna dana), često tijekom vikenda. Na taj se način želi s jedne strane omogućiti sudionicima da prije potpisivanja sporazuma imaju vremena posavjetovati se s odvjetnicima, obitelji ili drugim njima važnim osobama te još jednom razmisliti te, s druge strane, prilagoditi postupak pravnim zahtjevima koji se tiču rokova provedbe o kojima je ranije bilo riječi. Također, pripremni postupak je složeniji, karakterizira ga puno komunikacije s roditeljima, odvjetnicima sudionika i sa sucem koji je zadužen za pojedini slučaj (s ciljem motiviranja sudionika na sudjelovanje i razjašnjavanje uloga svih uključenih u postupak, pri čemu ističemo iznimno važnu ulogu sudaca i odvjetnika) te koordinacija o mjestu i datumu provedbe medijacije. ${ }^{71}$

Jedna od mogućnosti, kojoj smo danas slijedom prilagodbi vezanih uz pandemiju možda više otvoreni, jest i mogućnost korištenja tzv. medijacije na daljinu,

70 Vidi više u: Paul; Walker, op. cit. u bilj. 67.

71 O tome više: Kiesewetter; Paul, op. cit. u bilj. 68. 
u online okružju. ${ }^{72}$ Dakako, jedna od temeljnih zamjerki takvom postupanju jest nepostojanje izravnog kontakta, tzv. licem u lice, no zagovornici te ideje podsjećaju da osobito u međunarodnim otmicama postoji fizička udaljenost, koju tehnologija prevladava i ostvaruje se blizina. ${ }^{73} \mathrm{E}$. Cunha tako predlaže i korištenje tzv. hibridnog modela medijacije prema kojem bi se provodila i medijacija na daljinu i medijacija in vivo. ${ }^{74}$

Da bi netko sudjelovao u postupku obiteljske medijacije, potrebna je procjena pretpostavki za sudjelovanje, koju provodi obiteljski medijator u predmedijacijskom susretu ili tijekom prvog susreta s obiteljskim medijatorom. Tri su pretpostavke za sudjelovanje u obiteljskoj medijaciji koje se procjenjuje i kada je riječ o slučajevima međunarodne otmice djece. Prva je postoji li spremnost roditelja na suradnju, pri čemu se misli na postojanje minimuma interesa i želje za "sjedanjem za isti stol" uz postojeće nepovjerenje u mogućnost suradnje. ${ }^{75}$ Čini se da je upravo element spoznaje o vrijednostima obiteljske medijacije presudan u provedbi postupka. Iskazivanje spremnosti na suradnju očituje se i u prihvaćanju osnovnih pravila i načela medijacije od strane sudionika, koja se izražava usmeno ili potpisivanjem Sporazuma o uključivanju u postupak obiteljske medijacije.

Druga je pretpostavka kompetentnost sudionika, odnosno sposobnost sudionika da sami donose odluke koje su za njih važne. Većina ljudi ima sposobnost izraziti svoje interese i potrebe, raspravljati o njima i donijeti "svoje" odluke, neovisno o socijalnom, ekonomskom ili obrazovnom statusu ako im se pruži mogućnost. ${ }^{76}$ Sposobnost sudionika može biti ograničena psihofizičkim razlozima kao što su bolest, razvojni status ili pak zloupotreba opojnih sredstava te u tim slučajevima obiteljska medijacija nije adekvatna intervencija.

Treća je pretpostavka ravnoteža moći koja treba biti takva da je pregovaranje moguće jer u situacijama kada je prisutna značajna razlika u moći među sudionicima ni pregovaranje ni medijacija nisu mogući. Velika neravnoteža moći ogleda se u situacijama nasilja, prijetnji i zastrašivanja. Situacija međunarodne

72 Cunha, op. cit. u bilj. 19, str. 158; Župan; Šego, op. cit. u bilj. 7, str. 408. Više o provedbi obiteljske medijacije na daljinu može se pročitati u radu Vejmelka, L., Komunikacija među partnerima u digitalno doba: mogućnosti obiteljske medijacije, Ljetopis socijalnog rada, vol. 27., br. 2, 2020., str. $341-368$.

73 Cunha, op. cit. u bilj. 19, str. 173.

74 Ibid., str. 178.

75 Tako Roberts, op. cit. u bilj. 57, str. 305, navedeno prema Sladović Franz, op. cit. u bilj. 65.

76 Ibid. 
otmice djece jest specifična jer se može reći da roditelj kod kojeg se nalazi dijete ima veću moć, ali upravo je prostor obiteljske medijacije mjesto gdje se o tome raspravlja te je i to dijelom razlog dodatnog obrazovanja obiteljskih medijatora za područje međunarodne obiteljske medijacije, koje zahtijevaju primjenu složenih tehnika i vještina. Dužnost medijatora je prekinuti medijaciju ako procijeni neravnotežu moći koja će utjecati na proces odnosno sporazum, to jest ako procijeni da bi dogovor bio postignut u strahu od druge strane ili pod prisilom.

\section{ZAKLJUČNA RAZMATRANJA}

Prestanak bračne odnosno izvanbračne zajednice jedan je od najstresnijih događaja za (izvan)bračne drugove i djecu, čije posljedice osjećaju i jedni i drugi. Riječ je o procesu koji zahtijeva vrijeme za prilagodbu i reorganizaciju života, a posljedice za djecu ovise i o njihovoj životnoj dobi i o ponašanju roditelja za vrijeme razvoda i nakon njega ${ }^{77}$ Neka ponašanja roditelja u tom procesu mogu biti ekstremna. Jedno od takvih je nezakonito odvođenje ili zadržavanje djeteta preko granice države u kojoj je imalo uobičajeno boravište bez pristanka ili znanja drugog roditelja, tj. međunarodna otmica djeteta. Međunarodne otmice događaju se u slučajevima raspada braka i izvanbračnih zajednica roditelja te ostavljaju posljedice kod djece.

Ako je riječ o roditeljima koji su različitih nacionalnosti, državljanstava i države podrijetla, roditelj koji odvodi ili zadržava dijete to čini u državi svojeg podrijetla u kojoj je odrastao te u kojoj ima bolju socijalnu podršku. Različite okolnosti dovode do međunarodne otmice djeteta, koje često nisu unaprijed planirane. Sam čin međunarodne otmice, psihološke, socijalne i pravne posljedice koje iz njega proizlaze predstavljaju velik stres za dijete i za roditelje. Mogućnost dobrovoljnog povratka djeteta odnosno sporazumnog rješavanja ovog sukoba preporučuje se od strane svih prikazanih međunarodnih dokumenata kojima se regulira pitanje otmice djece - od Haške konvencije pa do nacionalnog zakonodavstva.

U hrvatskome pravnom okviru dva postupka u kojima bi se mogla potvrditi posebna vrijednost mirnog rješavanja obiteljskopravnih prijepora svakako su obvezno savjetovanje te, osobito, prvi sastanak obiteljske medijacije. Naime, upravo su ti postupci prilika za motiviranje roditelja na postizanje sporazuma kako bi se preventivno djelovalo, osnažilo roditelje, a postignuti su sporazumi svojevrsno jamstvo da do postupka međunarodne otmice djece neće doći. Time

77 O tome više: Haynes, J. M., The Fundamentals of Family Mediation, State University of New York Press, New York, 1994. 
se nadalje, kako je već spomenuto, potiču stranke na preuzimanje odgovornosti i samostalno odlučivanje, s čime je povezana veća razina vjerojatnosti da će se donesene odluke i poštovati. Na taj bi se način i sam postupak medijacije potvrdio kao brži, jednostavniji i ekonomičniji postupak koji donosi kratkoročne i, što je još važnije, dugoročne koristi. ${ }^{78}$

Dakako, postupak obiteljske medijacije u slučajevima međunarodne otmice djece ima svoje specifičnosti koje su vezane uz okolnosti provedbe, vremensko ograničenje, visoku razinu sukoba između roditelja, često potpuno prekinutu komunikaciju i vrlo narušen odnos povjerenja, uz kompliciran pravni okvir. Stoga je potrebno da se medijacija provodi od strane posebno educiranih medijatora za postupke međunarodne otmice, koji trebaju raditi u suvoditeljskom paru (poželjno različitih primarnih profesija, pravnik i psihosocijalno područje) kako bi se osigurala kvaliteta provedbe i time povećala šansa uspješnosti postupka u dijelu u kojem stručnjaci imaju utjecaja, a to je način provedbe i upravljanje procesom obiteljske medijacije. ${ }^{79}$

Sve osobe koje dolaze u kontakt s obiteljskim sukobima kao dio svoje profesionalne uloge, kao što su odvjetnici, suci, socijalni radnici, psiholozi, imaju priliku ponuditi roditeljima sudjelovanje u postupku obiteljske medijacije. ${ }^{80}$ Možemo se složiti s L. Parkinson, koja navodi nekoliko razloga zašto se često propusti informirati i usmjeriti roditelja na obiteljsku medijaciju, za koje smatramo da su prisutni i u hrvatskom kontekstu, a to su: nedovoljna informiranost o postojanju medijacije; nedostatak središnjeg popisa licenciranih obiteljskih medijatora kako bi dostupnost bila veća; troškovi medijacije - putovanja, prevoditelji, honorari; strah da će se zbog sudjelovanja u medijaciji odgoditi ročište na sudu te nedostatak modela medijacije koji bi se mogli prilagoditi europskom i neeuropskom kontekstu. ${ }^{81}$

S obzirom na to, potrebno je dodatno informirati i educirati stručnjake o postupku obiteljske medijacije i njezinim prednostima u postupcima međunarodne otmice djeteta kako bi roditeljima mogli pravodobno pružiti informaciju i o toj mogućnosti te na taj način možda i preventivno djelovati. Roditelji bi tako informaciju o mogućnosti obiteljske medijacije trebali dobiti i od odvjetnika i središnjeg tijela, u ministarstvu zaduženom za pitanje socijalne skrbi, centrima za socijalnu skrb i u sustavu pravosuđa, od sudaca i ostalih stručnjaka. Potrebno je

78 Slično i: Župan; Hoško, op. cit. u bilj. 49, str. 241.

79 Riveros; Coester-Waltjen, op. cit. u bilj. 66, str. 12.

80

Vrlo slično zaključuje i Mandija, op. cit. u bilj. 7, str. 70.

81 Parkinson, L., Family Mediation: Appropriate Dispute Resolution in a new family justice systems, Family law, Bristol, 2011., str. 405 - 406. 
nadalje obiteljsku medijaciju učiniti vidljivijim postupkom, ne samo za stručnjake već i za širu javnost, kako bi se uvidjele mogućnosti koje stoje na raspolaganju za rješavanje sukoba i sporova u takvim visoko stresnim situacijama. U suprotnom, obiteljska medijacija, osobito u slučajevima građanskopravnih, međunarodnih otmica djece ostaje iznimno koristan instrument neprepoznate vrijednosti.

\section{LITERATURA}

Alinčić, M., Europsko viđenje postupka obiteljskog posredovanja, Revija za socijalnu politiku, vol. 6, br. 3-4, 1999., str. 227-240. (http://dx.doi.org/10.3935/rsp. v6i3.280)

Bidaud, C.; Fulchiron, H.; Baret, B.; Brunerie, C.; Camuzat, A.; Delmas, C.; Fongaro, E.; Kessler, G.; Millerioux, G.; Panet-Marre, A.; Vessaud, R., A Chronicle of French Family Law: 2019, u: Brinig, M. (ur.), International Survey of Family Law 2020, Intersentia, Cambridge - Antwerp - Chicago, 2020., str. 115-134.

Branica, V., Obrazovanje obiteljskih medijatora u hrvatskom i međunarodnom kontekstu, Ljetopis socijalnog rada, vol. 27, br. 2, 2020., str. 231-245. (https://doi. org/10.3935/ljsr.v27il.377)

Cunha, E., The potential importance of incorporating online dispute resolution into a universal medation model for international child abduction cases, Connecticut journal of international law, vol. 24, br. 1, 2008., str. 155-180.

Čulo Margaletić, A., The Role of Lawyers in Family Law Disputes, Zbornik Pravnog fakulteta u Zagrebu, vol. 68, br. 2, 2018., str. 217-241.

European Union Agency for Fundamental Rights and Council of Europe, Handbook on European law relating to the rights of the child, Luxembourg, 2015., dostupno na: https://fra.europa.eu/sites/default/files/fra_uploads/fra-ecthr-2015-handbook-european-law-rights-of-the-child_en.pdf (15. travnja 2021.)

Godišnja statistička izvješća o primijenjenim pravima socijalne skrbi, pravnoj zaštiti djece, mladeži, braka, obitelji i osoba lišenih poslovne sposobnosti, te zaštiti tjelesno ili mentalno oštećenih osoba u Republici Hrvatskoj, od 2003. do 2019. godine, dostupna na stranicama resornog ministarstva: https:/mrosp.gov.hr/strategije-planovi-programi-izvjesca-statistika/4165 (15. travnja 2021.)

Guidelines for a better implementation of the existing recommendation concerning family mediation and mediation in civil matters, dostupno na: https://rm.coe.int/ 16807475b6 (15. travnja 2021.)

Hague Conference on private international law, Guide for good practice under the Hague Convention of 25 October 1980 on the Civil Aspects of International Child 
Abduction Cases: Mediation, 2012., dostupno na: https://assets.hcch.net/docs/ d09b5e94-64b4-4afe-8eel-ab97c98daa33.pdf (15. travnja 2021.)

Haynes, J. M., The Fundamentals of Family Mediation, State University of New York Press, New York, 1994.

Hrabar, D., Porodičnopravna zaštita djece državljana SFRJ odvedene u inozemstvo protivno odluci suda o njihovu čuvanju i odgoju, Zbornik Pravnog fakulteta u Zagrebu, vol. 39, br. 1, 1989., str. 45-54.

Jakovac-Lozić, D.; Klarin, A., Međunarodne otmice djece od strane roditelja, Zbornik radova Pravnog fakulteta u Splitu, vol. 34, br. 45-46, 1997., str. 73-96.

Khazova, O. A.; Mezmur, B. D., UN Committee on the Rights of the Child - Continued Reflections on Family Law Issues in the Jurisprudence of the CRC Committee: The Convention on the Rights of the Child@30, u: Brinig, M. (ur.), International Survey of Family Law 2020, Intersentia, Cambridge - Antwerp - Chicago, 2020., str. 337-363.

Kiesewetter, S.; Paul, C.C., Cross-Border Family Mediation, Wolfgang Metzner Verlag, Frankfurt, 2009.

Kruger, T., International Child Abduction, u: Ippolito, F. (ur.), Migrant children: challenges for public and private international law, Editoriale Scientifica, Napoli, 2016., str. 85-107.

Lowe, N.; Stephens, V., Global trends in the operation of the 1980 Hague abduction convention, Family law quarterly, vol. 46, br. 1, 2012., str. 41-86.

Lowe, N.; Stephens, V., Part I - A statistical analysis of applications made in 2015 under the Hague Convention of 25 October 1980 on the Civil Aspects of International Child Abduction - Global report - provisional edition, pending the completion of the French version (Preliminary Document No 11 B of October 2017), dostupno na: https://assets.hcch.net/docs/511f0cb3-2163-4fd1-92ce-e3fl6e304377.pdfhttp:// www.hcch.net/upload/wop/abduct201lpd08ae.pdf (15. travnja 2021.)

Mandija, L., Cross-border Disputes over Child Custody and Access Rights and the ECtHR Jurisprudence in the Case of Albania, u: Brinig, M. (ur.), International Survey of Family Law 2018, Intersentia, Cambridge - Antwerp - Chicago, 2018., str. 51-70.

McEleavy, P., The European Court of Human Rights and the Hague Child Abduction Convention: Prioritising Return or Reflection?, Netherlands International Law Review, vol. 62, 2015., br, 3, str. 365-405.

Medić Musa, I.; Božić, T., Haška konvencija o građanskopravnim aspektima međunarodne otmice djeteta (1980) - casus belli, u: Rešetar, B. (ur.), Pravna zaštita prava na (zajedničku) roditeljsku skrb, Pravni fakultet Osijek, Osijek, 2012., str. 161-197. 
Parkinson, L., Family Mediation: Appropriate Dispute Resolution in a new family justice systems, Family law, Bristol, 2011.

Paul, C.C.; Walker, J., A case for mediation: Family mediation in international child custody conflicts, World Arbitration \& Mediation Review, vol. 1, br. 4, 2007., str. 589-594.

Pavić, M.; Šimović, I.; Čulo Margaletić, A., Postupak ovrhe radi ostvarivanja osobnih odnosa roditelja i djece kao pretkazivač povrede prava iz Europske konvencije za zaštitu ljudskih prava i temeljnih sloboda, Godišnjak Akademije pravnih znanosti $\mathrm{Hr}$ vatske, vol. VIII, Posebni broj, 2017., str. 171-198.

Pérez-Vera, E., Explanatory Report on the 1980 Hague Child Abduction Convention, 1982., dostupan na: http://hcch.e-vision.nl/upload/expl28.pdf (15. travnja 2021.)

Praktični priručnik za primjenu Uredbe Bruxelles II.a, dostupno na: https://op.europa.eu/en/publication-detail/-/publication/f7d39509-3f10-4ae2-b993-53ac6b 9f93ed (15. travnja 2021.)

Recommendation no. $R$ (98) I of the Committee of Ministers to Member states on Family Mediation, dostupno na: https://rm.coe.int/CoERMPublicCommonSearchServices/DisplayDCTMContent?documentId=09000016804ecb6e (15. travnja 2021.)

Riveros, C.; Coester-Waltjen, D., Alternative dispute resolution in family disputes in Europe and Chile: Mediation, Direito GV Law review, vol. 15, br. 1, 2019., str. $1-14$.

Sladović Franz, B., Obilježja obiteljske medijacije, Ljetopis Studijskog centra socijalnog rada, vol. 12, br. 2, 2005., str. 301-320.

Šeparović, M., Dobrobit djeteta i najbolji interes djeteta u sudskoj praksi, Novi informator, Zagreb, 2014.

Šimović, I.; Majstorović, I., Povreda prava na obiteljski život u postupcima međunarodne otmice djece: o značenju načela žurnog postupanja, Hrvatska pravna revija, vol. 17, br. 1, 2017., str. 1-9.

Thorpe, M., Mediation to resolve child abduction issues for Hague and Non-Hague convention countries, Singapore Academy of law journal, vol. 30, Special issue, 2018., str. 575-586.

Vajić, N., The Interaction between the European Court of Human Rights and the Hague Child Abduction Convention, u: Župan, M., (ur.), Private International Law in the Jurisprudence of European Courts - Family at Focus, Faculty of Law Osijek, Josip Juraj Strossmayer University of Osijek, Osijek, 2015., str. 285-293.

Vejmelka, L., Komunikacija među partnerima u digitalno doba: mogućnosti obiteljske medijacije, Ljetopis socijalnog rada, vol. 27., br. 2, 2020., str. 341-368. (https:// doi.org/10.3935/ljsr.v27i2.347) 
Župan, M.; Drventić, M.; Kruger, T., Cross-border removal and retention of a ChildCroatian Practice and European Expectation, International Journal of Law, Police and The Family, vol. 34, br. 1, 2020., str. 60-83. (https://doi.org/10.1093/ lawfam/ebz019).

Župan, M.; Hoško, T., Operation of the Hague 1980 Child Abduction Convention in Croatia, u: Župan, M. (ur.), Private International Law in the Jurisprudence of European Courts - Family at Focus, Faculty of Law Osijek, Josip Juraj Strossmayer University of Osijek, Osijek, 2015., str. 227-242.

Župan, M.; Šego, M., Medijacija u prekograničnim obiteljskim postupcima, u: Župan, M. (ur.), Prekogranično kretanje djece u Europskoj uniji, Pravni fakultet Sveučilišta Josipa Jurja Strossmayera u Osijeku, Osijek, 2019., str. 397-413.

\section{Propisi:}

Europska konvencija o ostvarivanju dječjih prava, Narodne novine, Međunarodni ugovori, br. 1/2010.

Kazneni zakon, Narodne novine, br. 125/2011, 144/2012, 56/2015, 61/2015, 101/2017, 118/2018, 126/2019.

Konvencija o gradanskopravnim vidovima međunarodne otmice djece, Narodne novine, Međunarodni ugovori, br. 8/2018.

Konvencija o kontaktima s djecom, Narodne novine, Međunarodni ugovori, br. $7 / 2008$.

Konvencija o nadležnosti, mjerodavnom pravu, priznanju, ovrsi i suradnji u odnosu na roditeljsku odgovornost i o mjerama za zaštitu djece, Narodne novine, Međunarodni ugovori, br. 5/2009.

Konvencija o pravima djeteta, Službeni list SFRJ - Međunarodni ugovori, br. 15/1990, Narodne novine, Međunarodni ugovori, br. 12/1993 i 20/1997.

Obiteljski zakon, Narodne novine, br. 103/2015, 98/2019, 49/2020.

Ovršni zakon, Narodne novine, br. 112/2012, 25/2013, 93/2014, 55/2016, 73/2017, 131/2020.

Pravilnik o načinu postupanja i suradnje suca, stručnog radnika centra za socijalnu skrb i policijskog službenika za mladež prilikom prisilnog oduzimanja i predaje djeteta, Narodne novine, br. 48/2016, 112/2018.

Uredba Vijeća (EU) 2019/1111 od 25. lipnja 2019. o nadležnosti, priznavanju i izvršenju odluka u bračnim sporovima i u stvarima povezanima s roditeljskom odgovornošću te o međunarodnoj otmici djece (preinaka), Službeni list Europske unije, L 178, 2.7.2019. 
Uredba Vijeća (EZ) br. 2001/2003 od 27. studenoga 2003. o nadležnosti, priznavanju i izvršenju sudskih odluka u bračnim sporovima $i$ u stvarima povezanim s roditeljskom odgovornošću, kojom se stavlja izvan snage Uredba (EZ) br. 1347/2000, Službeni list Europske unije, L 338, 23.12.2003., L 46, 18.2.2014.

Zakon o provedbi Konvencije o građanskopravnim vidovima međunarodne otmice djece, Narodne novine br. 99/2018.

Zakon o provedbi Uredbe Vijeća (EZ) br. 2201/2003 o području nadležnosti, priznanja i izvršenja sudskih odluka u bračnim sporovima i u stvarima povezanim s roditeljskom skrbi, Narodne novine, br. 127/2013.

\section{Sudske odluke:}

Europski sud za ljudska prava, Presuda u predmetu Andersena protiv Latvije, zahtjev br. 79441/17, presuda od 19. rujna 2019.

Europski sud za ljudska prava, Presuda u predmetu Bajrami protiv Albanije, zahtjev br. 35853/04, presuda od 12. prosinca 2006.

Europski sud za ljudska prava, Presuda u predmetu Maumousseau i Washington protiv Francuske, zahtjev br. 39388/05, presuda od 6. prosinca 2007.

Europski sud za ljudska prava, Presuda u predmetu R.S. protiv Poljske, zahtjev br. 63777/09, presuda od 21. srpnja 2015.

Europski sud za ljudska prava, Presuda u predmetu X protiv Latvije, zahtjev br. 27853/09, presuda Velikog vijeća od 26. studenoga 2013.

Sud Europske unije, Presuda u predmetu C-111/17 PPU, OL v PQ, ECLI:EU:C:2017:436

Sud Europske unije, Presuda u predmetu C-211/10 PPU, Doris Povse v Mauro Alpago, ECLI:EU:C:2010:400

Sud Europske unije, Presuda u predmetu C-491/10 PPU, Aguirre Zarraga v Simone Pelz, ECLI:EU:C:2010:828+ 
Summary

\section{Vanja Branica* \\ Irena Majstorovićs* \\ Ivan Šimović****}

\section{FAMILY MEDIATION AND POSSIBILITIES OF ITS USE IN INTERNATIONAL CHILD ABDUCTION CASES}

International child abduction is a phenomenon in the focus of experts for a long time. Nevertheless, it seems that the means of overcoming such difficult situations are often a bone of contention for different professions. The purpose of this paper is therefore threefold. Firstly, starting from the common perspective of law and social work, to shed additional light on the possibilities which are offered by family mediation, being a useful instrument of settling complicated conflicts and family disputes in general. Secondly, to analyse the advantages of use of family mediation in cases of international family abduction. And finally, to endeavour to provide an interdisciplinary insight into key legal sources combined with the knowledge of practical challenges of implementation of mediation procedures, so that the value of mediation in international child abduction cases would become more recognised.

To be more specific, the disruption of a marital or an extramarital union is by all means one of the most stressful events both for the partners and their children. It is a process demanding time to adjust and reorganise life, and the consequences for children depend not only on their age, but also on the behaviour of the parents during and after the divorce. Some behaviours on the part of the parents can become extreme in this process, and one of such extremes is the wrongful removal or retention of the children across the borders of the state of their habitual residence without the knowledge or consent of the other parent, i.e. international child abduction. Such an act causes significant psychological, social and legal consequences, all imposing pressure on the child and the parents. One of the optimal solutions to this complex problem is alternative dispute resolution, which is advocated for in a plethora of documents analysed in this paper.

Vanja Branica, Ph. D., Associate Professor, Faculty of Law, University of Zagreb, Trg Republike Hrvatske 14, 10000 Zagreb; vanja.branica@pravo.hr;

ORCID ID: orcid.org/0000-0001-5184-6645

** Irena Majstorović, Ph. D., Professor, Faculty of Law, University of Zagreb, Trg Republike Hrvatske 14, 10000 Zagreb; irena.majstorovic@pravo.hr;

ORCID ID: orcid.org/0000-0002-4937-5968

**** Ivan Šimović, Ph. D., Assistant Professor, Faculty of Law, University of Zagreb, Trg Republike Hrvatske 14, 10000 Zagreb; isimovic@pravo.hr;

ORCID ID: orcid.org/0000-0002-0222-5073 
Family mediation is one of the recommended procedures, in which the parents independently and with the assistance of a third neutral person have the possibility of reaching an agreement important for their lives and the lives of their children. The process of family mediation in such specific circumstances has its particularities, linked to the challenges of its realisation, the time limits, a high level of conflict between the parents, a frequently complete breakdown of communication and the issue of mistrust, together with the complicated legal framework. It is therefore necessary that family mediation be carried out by specially educated professionals working in pairs (preferably a legal and a psychosocial professional), so that the quality of the procedure is enhanced thereby augmenting the possibility of its success.

All professionals in contact with family conflicts as a part of their professional role, such as attorneys-at-law, judges, social workers, psychologists have the opportunity to present to the parents the option of participating in the family mediation. Therefore, it is necessary to provide additional information and education of experts in the field of family mediation and its advantages in the international child abduction cases. In other words, it is always the purpose of family mediation to encourage parties to accept the responsibility and decide on their own, which leads to a better chance that they will respect the decision reached. Hence, mediation would be recognised as a faster, simpler and more economic procedure, bringing both short- and long-term benefits. It is also necessary to make family mediation a more visible procedure in general, so that the new options of resolving family disputes in such demanding situations can be explored. Otherwise, family mediation, especially in cases of international child abduction remains a very useful instrument of unrecognised value.

Keywords: Family mediation; international child abduction; Hague convention on the civil aspects of international child abduction; family 